\title{
ANALISIS INDUSTRI PENGOLAHAN SUSU DI INDONESIA
}

\author{
Lim Sanny \\ Jurusan Manajemen, Fakultas Ekonomi dan Bisnis, Bina Nusantara University \\ Jln. K.H. Syahdan No 9, Kemanggisan, Palmerah, Jakarta Barat 11480 \\ lsanny@binus.ac.id
}

\begin{abstract}
Milk is the main food for all ages. In addition, many products can be made from milk such as food, beverages, cheese, butter, yogurt, etc.. Opportunities milk processing industry in Indonesia is very good, considering that Indonesia with a population based on census 2010 reached 237.6 million people. If viewed from the supply side, current milk production in Indonesia is still very low, the number of dairy farmers around 118.75 thousand breeders. National dairy cow productivity stagnated, the average milk production ranges between 8-12 liters per day, with a scale of 2-3 maintenance per family breeder breeding. In addition, 90\% of milk production resulting from farm people, so the quality and productivity cannot fulfill the demand of milk in the country, so most still have to import.
\end{abstract}

Keywords: productivity, quality, milk processing industry

\begin{abstract}
ABSTRAK
Susu adalah bahan makanan utama bagi seluruh usia. Selain itu banyak produk dapat dibuat dari susu seperti makanan, minuman, keju, mentega, yogurt, dll. Peluang industri pengolahan susu di Indonesia sangat baik, mengingat Indonesia dengan jumlah penduduk berdasarkan sensus 2010 mencapai 237,6 juta jiwa. Jika dilihat dari sisi supply, saat ini produksi susu di Indonesia masih sangat rendah, Jumlah peternak susu sekitar 118,75 ribu peternak. Produktivitas sapi perah nasional mengalami stagnasi, rata-rata produksi susu berkisar antara 8-12 liter per hari, dengan skala pemeliharaan per KK peternak 2-3 ekor induk. Selain itu 90\% dari produksi susu dihasilkan dari peternakan rakyat, sehingga kualitas dan produktivitas belum dapat memenuhi permintaan susu di dalam negeri, sehingga sebagian besar masih harus impor.
\end{abstract}

Kata kunci: produktivitas, kualitas, industri pengolahan susu 


\section{PENDAHULUAN}

Industri dalam Undang-undang Nomor 5 Tahun 1984 tentang Perindustrian didefinisikan sebagai kegiatan ekonomi yang mengolah bahan mentah, bahan baku, barang setengah jadi dan/atau barang jadi menjadi barang dengan nilai yang lebih tinggi untuk penggunaanya, termasuk kegiatan rancang bangun dan perekayasaan industri. Proses pembuatan barang dan jasa memerlukan transformasi sumber daya menjadi barang. Untuk dapat produktif dan mempunyai nilai tambah pada suatu produk, maka efisiensi sangat diperlukan. Salah satu industri yang mempunyai peluang yang cukup baik adalah industri pengolahan susu, mengingat susu adalah salah satu kebutuhan pokok yang dibutuhkan oleh seluruh kelompok usia. Selain itu, banyak produk dapat dibuat dari susu seperti makanan, minuman, keju, mentega, yogurt, dll. Dari sisi manfaat, susu mempunyai manfaat yang sangat besar terutama bagi anak-anak. Dengan minum 2 gelas susu setiap hari secara teratur setiap hari, akan mengurangi resiko keropos tulang di usia senja. Dari sisi permintaan, kebutuhan susu nasional setiap hari mencapai 4 juta hingga 6 juta liter (Antara News, Januari 2010). Peluang industri pengolahan susu di Indonesia sangat baik, mengingat Indonesia dengan jumlah penduduk berdasarkan sensus 2010 mencapai 237,6 juta jiwa atau 3,5 juta lebih dari prediksi sebelumnya dan jika diprediksi kenaikan populasi sebesar 1,66\%, maka di tahun 2020 mencapai 288 juta orang. Tabel berikut menggambarkan tren laju pertumbuhan penduduk di Indonesia.

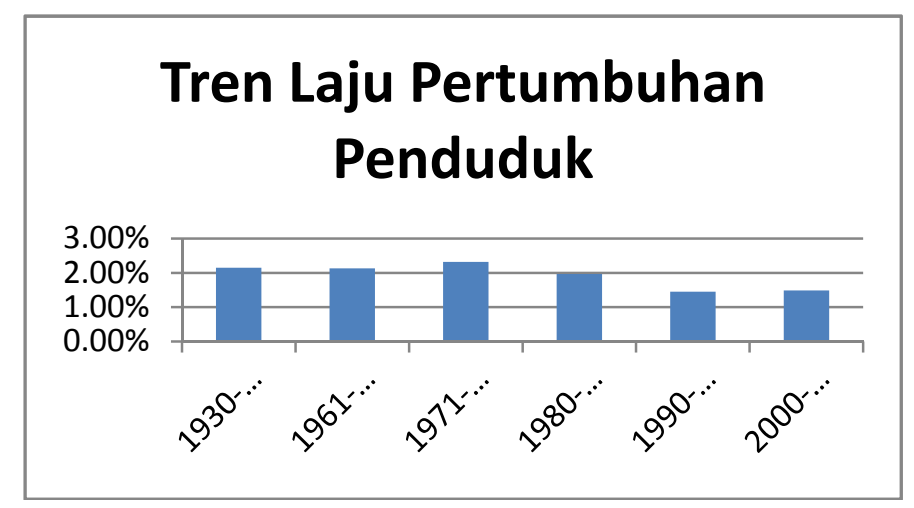

Gambar 1 Perkembangan jumlah penduduk Indonesia

Pengembangan Industri Pengolahan Susu berdasarkan Peraturan Presiden No.28 Tahun 2008 tentang Kebijakan Industri Nasional, untuk kelompok industri pengolahan susu dibagi menjadi 2 yaitu jangka menengah dan jangka panjang. Jangka menengah, yaitu (1) mengembangkan industri pakan ternak skala kecil dengan memanfaatkan sumber bahan pakan dalam negeri; (2) peningkatan mutu pakan ternak dalam upaya meningkatkan produktivitas susu segar; (3) meningkatkan populasi ternak sapi; (4) meningkatkan kepemilikan sapi oleh peternak dari 2- 5 sapi/peternak menjadi 10 sapi/peternak; (5) meningkatkan produktivitas ternak sapi dari 8-12 liter per ekor/hari menjadi 20 liter per ekor/hari; (6) peningkatan kualitas susu segar melalui bantuan ketrampilan cara perah, bantuan peralatan (cooling unit), dan penerapan Good Farming Practices (GFP) serta Good Handling Practices (GHP); (7) peningkatan kemitraan antara Industri Pengolah Susu dengan peternak sapi perah dan koperasi; (8) meningkatkan daya saing industri pengolahan susu melalui harmonisasi tarif bea masuk antara produk jadi susu dengan bahan baku; (9) meningkatkan kompetensi SDM khususnya dalam ketrampilan teknis \& teknologis pakan ternak dan usaha peternakan; (10) pengembangan industri permesinan pengolah susu; (11) pengembangan skema pembiayaan kepemilikan bibit sapi unggul; (12) meningkatkan konsumsi susu nasional. 
Jangka panjang, yaitu (1) meningkatkan populasi ternak sapi; (2) meningkatkan kepemilikan sapi oleh peternak dari 2- 5 sapi/peternak menjadi diatas 10 sapi/peternak; (3) meningkatkan produktivitas ternak sapi dari 8-12 liter per ekor/hari menjadi di atas 20 liter per ekor/hari; (4) meningkatkan penguasaan teknologi dalam upaya peningkatan mutu susu olahan; (5) mengembangkan diversifikasi produk susu olahan yang mempunyai daya saing tinggi di pasar dunia/ekspor; (6) peningkatan kerjasama dalam upaya pengembangan teknologi proses dan diversifikasi produk.

Hasil kajian Priyanti \& Saptati (2009) dalam dampak harga susu dalam negeri di tingkat peternak, dengan mengambil kasus Koperasi Peternak Sapi Bandung Utara di Jawa Barat mengungkapkan bahwa kenaikan harga susu di pasar internasional juga menyebabkan naiknya harga susu segar di tingkat peternak. Harga susu dunia meningkat sangat tajam pada periode 2006-2007 mencapai 74 persen. Di dalam negeri, hal tersebut direspon dengan kenaikan harga susu di tingkat peternak yang hanya mencapai 22 persen. Dihitung atas dasar harga full cream milk powder (susu bubuk) setara dengan $8 \mathrm{~kg}$ susu segar, maka rata-rata harga susu segar di tingkat peternak baru mencapai 62 persen dibandingkan dengan harga susu impor setara susu segar. Kondisi ini menunjukkan bahwa harga susu dalam negeri sangat kompetitif dibandingkan dengan harga susu dunia. Selanjutnya dikemukakan bahwa elastisitas harga penawaran susu segar dan harga konsentrat di tingkat peternak masing-masing cukup tinggi. Hasil ini menunjukkan bahwa kenaikan harga susu segar ternyata juga diimbangi dengan kenaikan harga konsentrat, sehingga perlu upaya substitusi komponen bahan pakan penyusun konsentrat.

\section{METODOLOGI PENELITIAN}

Jenis data yang digunakan dalam penelitian ini adalah data sekunder yang diperoleh dari Biro Pusat Statistik (BPS), Departemen Perdagangan, Departemen Perindustrian, CIC Consulting, Gabungan Koperasi Susu Indonesia (GKSI), data dari perusahaan industri pengolahan susu, serta beberapa perpustakaan dan hasil penelitian terdahulu.

\section{HASIL DAN PEMBAHASAN}

Jika dilihat dari sisi supply, saat ini produksi susu di Indonesia masih sangat rendah, Jumlah peternak susu sekitar 118,75 ribu peternak. Populasi sapi perah mengalami peningkatan dari 361 ribu ekor (2005) meningkat menjadi 487 ribu ekor (2009) meningkat sebesar 8,32 \% / tahun. Sejalan dengan peningkatan populasi, produksi juga meningkat dari 536 ribu ton pada tahun 2005 menjadi 608 ribu ton pada tahun 2009 meningkat sebesar 5,05 persen pertahun (Statistik Peternakan, 2009). Tingkat produksi tersebut ternyata belum mampu memenuhi seluruh permintaan konsumen di dalam negeri, padahal rata-rata konsumsi susu per kapita di Indonesia masih sangat kecil hanya sebesar 3.27\% pada tahun 2009 (Republika, September 2010).

Produksi per hari hanya 1,4 juta liter, Pada tahun 2009, besarnya total permintaan susu sebesar 2.728,6 ribu ton, sementara yang dapat dipenuhi dari penyediaan susu dalam negeri sebesar 685,2 ribu ton $(25,11 \%)$ dan $2.043,4$ ribu ton $(74,89 \%)$ harus di impor (BPS, 2009). Dengan demikian, Indonesia pada saat ini berstatus net-importir dan $97 \%$ produksi susu segar di Indonesia dari pulau jawa (Republika, September 2010). Indonesia secara geografis amat luas, indonesia memiliki industri strategis, untuk dapat tumbuh dan berkembang serta menjadi mandiri (Zuhal, 2008). Industri susu di Indonesia mempunyai struktur yang lengkap mulai dari peternak, pabrik pakan hingga pengolahan susu. Akan tetapi penyebaran jumlah penduduk di Indonesia tidak merata, penumpukan jumlah penduduk terjadi di pulau jawa. Tabel berikut adalah jumlah penduduk Indonesia tahun 2010 menurut pulau. 


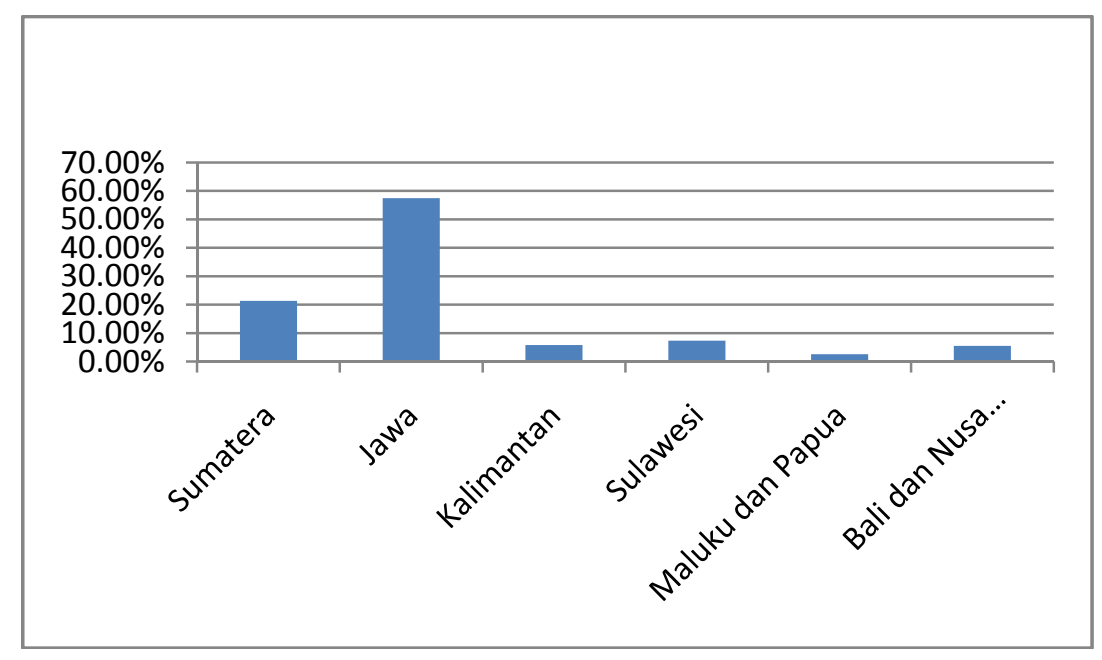

Gambar 2 Penyebaran jumlah penduduk berdasarkan pulau

Produktivitas sapi perah nasional mengalami stagnasi, rata-rata produksi susu berkisar antara 8-12 liter per hari, dengan skala pemeliharaan per KK peternak 2-3 ekor induk. Berikut adalah 84ndus perkembangan perusahaan sapi perah di Indonesia dari tahun 2000 hingga 2009.

Tabel 1 Tabel Perusahaan Sapi Perah di Indonesia

\begin{tabular}{|c|c|c|c|c|c|c|c|c|c|c|}
\cline { 2 - 11 } \multicolumn{1}{c|}{} & 2000 & 2001 & 2002 & 2003 & 2004 & 2005 & 2006 & 2007 & 2008 & 2009 \\
\hline PMA & & & & & & 1 & & & & \\
\hline PMDN & 14 & 13 & 15 & 30 & 18 & 12 & 11 & 10 & 10 & 9 \\
\hline Lainnya & 391 & 409 & 402 & 355 & 335 & 347 & 479 & 507 & 89 & 85 \\
\hline
\end{tabular}

Produksi susu dalam negeri sebagian besar masih tergantung dari peternakan sapi perah rakyat, yaitu sebesar 90\% dari produksi susu dihasilkan dari peternakan rakyat. Selain itu, kualitas susu (berdasarkan jumlah mikroba susu) secara umum masih belum mampu mencapai standar mutu. Kebijakan meningkatkan produksi susu nasional bukan hanya berdampak pada perbaikan gizi masyarakat, melainkan juga peningkatan kesejahteraan peternak, kebangkitan ekonomi pedesaan, pengembangan industry minuman, dan menekan pengangguran, terutama di pedesaan (Kompas, Januari 2009).

Industri pengolahan susu di Indonesia mempunyai peluang yang sangat baik, dilihat dari nilai investasi para investor tahun 2009, BKPM menerbitkan izin usaha tetap dan izin prinsip untuk delapan perusahaan susu. Total investasi mencapai US\$ 56,757 juta dan Rp 10,2 triliun. Delapan perusahaan susu terbesar di Indonesia antara lain PT Ajinomoto Calpis Beverage Indonesia, PT Frisian Flag Indonesia, PT Puri Purnama Delodyeh, PT Cisarua Mountain Dairy, PT Sari Husada, PT Danone Indonesia, dan PT Indolakto. Perusahaan-perusahaan tersebut memproduksi beragam jenis susu, mulai susu sapi segar, yoghurt, jelly puding, pasteurilize milk, acidif milk, susu kental manis, susu steril, hingga susu bubuk. Industri pengolahan susu di Indonesia akan tumbuh sebesar $10 \%$ per tahun, mengingat bertumbuhnya industri makanan dan minuman yang menggunakan susu sebagai bahan baku nya. Selain itu, dengan meningkatnya kesadaran masyarakat akan kesehatan merupakan peluang baru bagi perusahaan minuman susu olahan untuk menciptakan variasi produk susu olahan. Berikut adalah data industri pengolahan susu di Indonesia (Kontan, Desember 2009). 
Tabel 2 Data Industry Pengolahan Susu di Indonesia

\begin{tabular}{cl}
\hline No & \multicolumn{1}{c}{ Nama Perusahaan } \\
\hline 1 & Anugrah \\
2 & PT. Australia Indomilk Industry \\
3 & PT. Baru Bajak \\
4 & PT. Fajar Taurus \\
5 & PT. Firemost \\
6 & PT. Frisian Flag Indonesia \\
7 & GKSI Divisi Usaha Pengolahan Susu \\
8 & GKSI \\
9 & PT. Indomurni Diary Industri \\
10 & Karunia \\
11 & PD. Mamin Kertasari \\
12 & Kop Ternak Bandung Selatan \\
13 & PT. Nestle Indonesia \\
14 & PT. Netania Kasih Karunia Rembang \\
15 & Pasific Indo Dairy \\
16 & PT. Sarihusada \\
17 & PT.Sasana Citra Husada \\
18 & PT.Sugizindo \\
19 & Surya Dairy Farm \\
20 & Susu Bubuk Mirota KSM Inc \\
21 & Tunggal \\
22 & PT. Ultra Jaya Milk \\
23 & Yummy Food Utama \\
\hline
\end{tabular}

Dilihat dari sisi konsumsi, sampai saat ini konsumsi masyarakat Indonesia terhadap produk susu masih tergolong sangat rendah, dilihat dari persentase pengeluaran rata-rata per kapita hanya sekitar 3\%, berikut adalah tabel perkembangan persentase pengeluaran rata-rata per kapita untuk konsumsi susu.

Tabel 3 Perkembangan Persentase Pengeluaran Rata-Rata Per Kapita Konsumsi Susu

\begin{tabular}{|c|r|r|r|r|r|r|r|r|r|}
\hline Tahun & 1999 & 2002 & 2003 & 2004 & 2005 & 2006 & 2007 & 2008 & 2009 \\
\hline$\%$ & 2.91 & 3.28 & 3.04 & 3.05 & 3.12 & 2.96 & 2.97 & 3.12 & 3.27 \\
\hline
\end{tabular}

Jika dibandingkan dengan negara berkembang lainnya. Konsumsi susu per kapita di Indonesia saat ini hanya 10,5 kg per kapita per tahun. Sedangkan di Negara ASEAN mencapai $28 \mathrm{~kg}$ per kapita per tahun. Masyarakat Indonesia mengkonsumsi susu segar sekitar $18 \%$ dari total konsumsi susu, sementara 82\% merupakan konsumsi susu bubuk. Sedangkan untuk Industri Pengolahan Susu (IPS) masih sangat tergantung dengan bahan baku dari impor yang mencapai $70 \%$. Konsumsi susu di Indonesia sebesar 11,9 liter per kapita per tahun masih sangat sedikit jika dibandingkan dengan Negara-negara tetangga lainnya, misalnya India sebesar 42,8 liter per kapita per tahun, Malaysia 22,1 liter per kapita per tahun, Thailand 31,7 per kapita per tahun dan Vietnam 12,1 liter per kapita per tahun. Saat ini produksi susu di Indonesia hanya dapat memenuhi $25-30 \%$ dari permintaan susu nasional, sehingga sisanya harus diimpor dari beberapa Negara, seperti New Zealand yang merupakan Negara pengekspor susu terbesar di dunia. New Zealand mengekspor 70\% dari total impor susu di Indonesia, sisanya yang 30\% diimpor dari Australia dan Philipina. Kondisi ini sangat membuat Indonesia memiliki ketergantungan yang sangat tinggi (Republika, 2009). Dari konsumsi sebesar 11,9 liter per kapita per tahun tersebut, konsumsi susu cair yang dikonsumsi masyarakat Indonesia hanya $18 \%$ nya saja. Konsumsi susu cair di Indonesia sangat rendah apabila dibandingkan dengan India yang 98\%, Thailand 88\%, Cina 76,5\%. Padahal susu cair lebih baik daripada susu bubuk, karena kandungan gizinya lebih banyak. 
Jika ditinjau dari sisi harga, akhir-akhir ini harga susu global terus meningkat. Pada bulan april 2010, harga susu bubuk di pasar dunia naik ke level tertinggi dalam 21 bulan terakhir. Hal tersebut terjadi karena tingginya permintaan, sedangkan persediaan mulai berkurang karena pengaruh cuaca yang kurang baik di New Zealand, sebagai Negara pengekspor susu terbesar di dunia. Pengiriman susu bubuk untuk bulan Juni 2010 naik 24\% menjadi US\$ 4.092 per metrik ton. Nilai ini mendekati rekor tertingginya sejak Juli 2008. Sebelumnya, harga pengiriman susu bubuk dari Juli hingga September 2009 naik 22\% menjadi US\$ 4.061 per ton. Sementara pengiriman susu untuk periode Oktober hingga Desember naik 18\% menjadi US\$ 3.773 per ton (Kontan, juni 2010). Akibat kenaikan harga susu global, harga jual susu ke konsumen juga ikut meningkat sehingga konsumsi susu makin menurun karena daya beli masyarakat pun menurun. Adapun data populasi sapi perah dan produksi susu nasional Indonesia adalah sebagai berikut:

Tabel 4 Data Populasi Sapi Perah dan Produksi Susu Nasional Indonesia

\begin{tabular}{ccc}
\hline Tahun & Populasi Sapi (ekor) & Produksi Susu (Ton) \\
\hline 2003 & 374000 & 553400 \\
2004 & 364000 & 549900 \\
2005 & 361000 & 536000 \\
2006 & 369000 & 616500 \\
2007 & 378000 & 636900 \\
\hline
\end{tabular}

Industri susu di Indonesia masih mempunyai peluang yang cukup baik, oleh karena itu perlunya penanganan yang baik yang harus segera dilakukan, mengingat masih rendahnya produksi susu di Indonesia, akan tetapi penurunan terjadi mulai tahun 2007 hingga kini seperti terlihat di tabel berikut.

Tabel 5 Produksi susu perusahaan sapi perah

\begin{tabular}{ccc}
\hline Tahun & $\begin{array}{c}\text { Jumlah Volume } \\
\text { ( ribuan Liter) }\end{array}$ & $\begin{array}{c}\text { Nilai } \\
\text { ( Juta Rupiah ) }\end{array}$ \\
\hline 2000 & $34,290.80$ & $55,826.83$ \\
2001 & $35,171.80$ & $59,815.11$ \\
2002 & $37,013.33$ & $65,969.26$ \\
2003 & $31,639.38$ & $59,634.51$ \\
2004 & $34,102.13$ & $67,347.55$ \\
2005 & $33,041.83$ & $73,827.14$ \\
2006 & $39,680.25$ & $89,454.68$ \\
2007 & $45,036.63$ & $125,831.68$ \\
2008 & $19,439.21$ & $60,151.99$ \\
2009 & $19,210.49$ & $59,535.43$ \\
\hline
\end{tabular}




\section{PENUTUP}

Perjanjian ASEAN-China Free Trade Agreement (ACFTA) mulai menebar ancaman bagi industri susu di Indonesia. Dengan adanya per tersebut, maka tarif biaya masuk produk susu antar negara Asean dan China menjadi 0\%. Fasilitas ACFTA itu dipastikan akan membuat produsen susu asing berbondong-bondong masuk ke pasar Indonesia. Selain karena fasilitas bea masuk 0\%, kondisi itu juga dipicu masih rendahnya kapasitas produksi susu di Indonesia. Dengan fasiltas ACFTA, harga susu impor lebih murah daripada susu nasional. Saat ini harga susu nasional 3.600 rupiah per liter sedangkan harga susu impor 2.000 rupiah hingga 3.000 rupiah per liter. Selain tingginya harga susu nasional, produsen susu olahan terpaksa harus mengimpor bahan baku susu, karena kualitas susu nasional belum sesuai dengan kriteria yang ditetapkan. Buruknya kualitas susu di tingkat peternak sapi perah menyebabkan $70 \%$ bahan baku industri susu dalam negeri seperti whey protein concentrate, lactose, skim milk powder, butter milk powder, masih harus diimpor. Dari sisi peluang, Indonesia secara geografis amat luas, indonesia memiliki industri strategis, untuk dapat tumbuh dan berkembang serta menjadi mandiri. Industri susu di Indonesia mempunyai struktur yang lengkap mulai dari peternak, pabrik pakan hingga pengolahan susu. Akan tetapi, hal tersebut harus diimbangi pula dengan produktivitas serta kualitas dari susu sebagai bahan baku. Untuk dapat meningkatkannya perlu adanya program pembinaan terhadap para petani susu sapi, karena 90\% dari produksi susu sapi dihasilkan dari para petani.

\section{DAFTAR PUSTAKA}

Anonim. (2010, 27 September). Mentan: 70\% konsumsi susu Indonesia impor. Republika Online. Diakses pada 3 Desember 2010.

Anonim. (2010, Januari). Oligopoli pasar susu rugikan peternak kecil. Antara News. Diakses pada 19 februari 2010.

Anonim. (2009, Desember). Produksi susu dan prospek industri susu di China. Kontan.

Anonim. (2009, 29 Januari). Peternak menjadi bumper industri susu. Kompas.

Presiden Republik Indonesia. (2008). Peraturan Presiden Republik Indonesia No. 28 Tahun 2008 tentang Kebijakan Industri Nasional.

Priyanti, A., \& Saptati. (2009). Dampak harga susu dalam negeri di tingkat peternak. Jurnal IPB, Bogor.

Biro Pusat Statistik, (2009). Statistik Peternakan. Jakarta: BPS.

Zuhal. (2008). Kekuatan daya saing Indonesia. Jakarta: Gramedia Kompas. 